\title{
The Trilemma of the Nation-State in the Middle East: Diversity, Terrorism and Islamic Constitutionalism
}

\author{
Mohamed Moussa, (LLM, Harvard Law School) \\ $\mathrm{PhD}$ candidate, Cambridge University, Faculty of Law
}

Doi: 10.19044/elp.v6no1a4

URL:http://dx.doi.org/10.19044/elp.v6no1a4

\begin{abstract}
The European modern nation-state model was imported to the MiddleEast as a readymade form of governance. Yet, since its adoption the region has witnessed three unprecedented phenomena. First, a rise of Islamic movements some of which peacefully while others violently challenge the premises of the nation-state. Second, an eruption of sectarian violence to unprecedented level in the region's history. Third, a glaring paradox evidenced through a bloody division caused by a call of Islamic unity in addition to religious radicalization triggered by secularization. As an alternative path, the paper ponders on the promises and pitfalls of supplementing the existing nation-states with a multilevel constitutional system.
\end{abstract}

Keywords: Multilevel Governance; Diversity; Sharia; Terrorism; Nationstate.

\section{Introduction:}

Following the institutional and intellectual collapse of what Feldman terms "the classical Islamic constitutional order" (Feldman, 2012), the nationstate model was imported from Europe as a readymade form of governance (Hallaq, 2014). However, it soon appeared that there exists an irreconcilable "discord" between the conceptual and institutional foundation of the indigenous Islamic law and the nation-state and its concomitant modern legal system (Hallaq, 2014). A discord that still affects rule of law, peaceful coexistence (Gurtman, 2015) and more importantly the public's collective memory on what represents justice (Feldman, 2012). This makes the public more vulnerable to radical propaganda that exploits their romanticized memories about the past leading the region into a vicious circle of intolerance and violence. 


\section{I.:}

As the nation-state was making its way through the newly decolonized world, Muslim majority countries witnessed a rise of various Islamic movements (Esposito, 2007). Despite the vastly divergent ideologies of these movements, they share a common objective; a call for return to Islamic law and united government; a call that challenges the premises of nation state. Alarmingly, this call is increasingly gaining grassroots popularity. A number of recent polls show that majorities in Muslim countries favor political unification on Islamic basis (Pankhurst, 2007). At the same time, they show deep affinity for democracy (Pankhurst, 2007).

At the heart of these grassroots calls lies a three-prong trilemma which is closely intertwined:

First, a subtle connection is traceable between official response to these calls and growth of terrorism. A number of scholars have illustrated how terrorism is a radical form of protest when people "lack the usual outlets for registering their protests" (Sunstein, 2014). Therefore, suppressing or ignoring these grassroots calls instead of, either refuting their conceptual foundation or taming them into a more acceptable paradigm, creates an underground market to channel them (Tomass, 2012). Unfortunately, underground networks tend to, as Sunstein argues, constitute a" breeding ground for extreme movement" (2014). Additionally, a relationship exists between public opinion on terrorism causes and the growth of its recruitment appeal (Gurr, 1998). A common denominator for radicalized individuals is sympathy toward the terrorist group's cause (Maeghin, 2016) and that terrorist groups use propaganda to draw in these vulnerable individuals (Berger and Morgan, 2015). Unsurprisingly then, statistics indicate that the dream of a united Islamic government has been extensively fantasized by terrorist Islamic movements and, thus, has become a key factor in terrorism recruitment (NATO, 2016).

Second, a principal reason for the invention of the nation-state in the modern era was to create ethno-culturally homogenous societies as a means to reinforce peaceful co-existence (Elazar, 2014). Yet, since its adoption in the Middle-East sectarian violence has erupted and religious conflicts continue to tear down the region in an unprecedented level in its history (Elazar, 2014). While this might be equally applicable to many parts of the developing world that adopted the nation-state (Elazar, 2011), a unique trait is peculiar to the Middle-East. Historically the region prior to the nation-state has managed to accommodate religious diversity in universal states (Elazar, 2011). Muslims, Christians, Jews as well others have co-existed for several centuries in Iraq, Egypt and Jerusalem with almost incomparable violent incidents. The unfortunate outcome the region is presently facing leads people to comparison 
with the past which fuels the disdain of nation-state and paves the way for more calls of reclaiming the old forms of governance.

Third, is what should be termed " Muslims' modern double paradox". While Islam is the driving force of calls for unification, it is at the same time a key reason of division. Islam has no monolithic clerical authority; Muslims hold widely contradicting views of Sharia. In the absence of an effective constitutional framework for religious diversity, Muslims have fallen in a "perennial state of disunity" (Opwis, 2005) which has often led to sectarian violence and civil war (Owen, 2006). Worse still, while disagreement on Sharia should make legal secularism a logical option, judging from the overwhelming evidence of the past century shows otherwise (Hashemi, 2009). Secular and quasi-secular MENA regimes did not fare better in diluting the intensity of these calls. Worse still, government imposed secularism often produced more radicalism (Feldman, 2007). Evidence includes the subsequent rise of Islamic revolution in Pahlavis Iran; rise of Qutbism in Nasser's Egypt; and Tunisia, a pioneer in Arab legal secularism, tops the world in ISIS recruits (Benmelech and Klor, 2016). Even in Turkey, sizable number of citizens regularly vote for Islamic parties (Feldman, 2007) as evidenced by the incumbent Islamist AKP's fifteen year rule, not to mention that Turkey ranks third in ISIS recruits (Elazar 2014).

To approach these dilemmas, it would be unwise to not to ponder on the possibility of adopting a different paradigm of governance. While nationstate was the dominant political model in the past century, a growing body of literature favors a departure from the classical nation-state towards federalism as a tool for managing religious/ethnic conflicts (Elazar, 2014). Advocates of this view argue that the existence of multi-tiers of governance help diverse societies share power through engineering a fit between the dictates of segmented local autonomy and adherence to common constitutional norms (Choudry, 2011). However, for this model of governance to transpire in the region, there are two challenges; theoretical and political that this paper tackles and offers possible routes to overcome them. What is meant by theoretical challenges is to envision the institutional design of the model and by what is meant by the political is how to manifest it into reality.

\section{Theoretical Design: hurdles and possible solutions}

The theoretical challenge is twofold, first while regions that have adopted federal and multilevel governance shared some features with the Middle East, one should not overlook the fact the latter region has one of the world's strongest religious establishment. In the Middle-East religion cuts deeply in the social fiber and continues to influence not only politics but also political life as detailed earlier. 
While as noted-above that Sharia's non monolithic nature has led to modern Muslim's double paradox, it is noteworthy that the very same nature has provided Islamic law with unequaled flexibility. This has helped Islamic law to adapt to customs and regional diversity for several centuries. This makes Islamic law, I argue, a double edged sword, if properly used could uphold cooperation and diversity as it did in the past. While if it is blocked forcefully, it contributes to the afore-mentioned three problems.

One of many examples to illustrate that the application of Islamic law in the pre-modern nation state bore the potential for the establishment of pluralism and regional diversity (Jackson, 2003) is a case properly tackled by Sherman Jackson in his article on Diversity and the nation-state. In the fourteenth century Ibn Qayyim, the Hanbalite jurist addresses the question of how the Muslim authorities should respond to traditions of other religious communities within the Islamic empire when such practices are deemed morally repugnant to Islam. In particular, the opinion was relevant to Zoroastrians tradition of marrying their mothers and sisters. He laid down the rule governing minority religious practices that such practices are to be recognized under two conditions": 1) that the religious minorities who engage in them not present their case to a Muslim court; and 2) that these religious minorities believe these practices to be permissible according to their own religious tradition" (Jackson, 2003, p 106). Therefore, despite his moral disagreement he decided that the authority should abstain from intervening in banning such marriage.

It is to be remarked that this is not a reformist view but rather mainstream and even regarded by many as orthodox classical jurist. Therefore, there is room to find within the body of jurisprudence what upholds the theory of regional cooperation and religious diversity. This example among others refutes the mistaken yet widely shared claim that adopting Islamic law necessary entail imposing sharia in uniform fashion to oppress religious minorities (Jackson, 2003, p 105).

The second part of the theoretical challenge, is that institutional design and political thoughts do not develop overnight. Contemporary literaturewhether arguing for or against reconcilability of Islam and constitutionalismis limited to the nation-state model (El Fadl, 2012). Even earlier Islamic jurisprudence, that addressed every single topic at the time were always anemic on constitutionalism and models of governance except for the work of al-Mawardi, Abu Ya'la and al-Juwaini written centuries ago, that adhered to theoretical analysis without going beyond the status quo (Al-Baghdadi, 1981).

It would be unrealistically ambitious to expect this design to be offered through an article or even one book. Yet, disentangling the study of Islamic constitutionalism from the narrow scope of the nation-state towards a more flexible structure of comparative federalism and multilevel constitutionalism 
is needed. This new component could pave the way for new ideas and could stimulate further academic scholarship. Collaborative intellectual effort could help develop a more workable model. In the long run, this might lead to a paradigm shift in governance in the Middle-East.

\section{Political Realities of the region: Monnet Method}

Examining how to bring the model into existence logically comes after developing a theoretically sound model that builds on the existing nationstates. At such stage the main challenge would be how to get the existing regional powers to cooperate after years of distrust and radical nationalism.

While the US represents the strongest existing multilevel constitutional order which has continued to exist for almost for two and a half centuries unshaken, the EU has more valuable guidance due to the fact that it has imposed a new multi-layered constitutional system on a continent historically dominated by sovereign nation-states. Another reason of drawing on the EU experience is that the current Middle-East resembles post world war Europe. Namely, a conflict ridden region with nation-states pitted against one another.

Monnet, the genius framer of the EU remarkably avoided eradicating the existing nation-state model and identified instead common economic interest among conflicting states and develop gradual yet irreversible steps (Gilles, 2016) that would make cooperation a win-win situation. His long-term plan led to states gradually delegating their powers to a supranational body which statistically helped uproot intercommunal wars in the historically conflict ridden conflict. A similar approach might be very promising in the Middle-East region and could be the only path out of the region's blood bath.

\section{Conclusion}

Nation-state is not leaving the Middle-East in the foreseeable future, yet relying solely on it has led and will continue to lead to catastrophic outcomes. The paper suggests introducing a supplemental multilevelconstitutional order that builds up on the existing nation-states. Heeding the EU's experience could be useful yet the experience needs to be adapted to the region's different composition and peculiar features. The most salient of which is the strong religious establishment as well the historic ties of cooperation in the region. Collaborative intellectual thinking among the region's scholars is needed to rely on innovation instead of borrowing to carve out a model that reconciles the balance of the indigenous strong yet flexible Islamic establishments and the dictates of modern constitutionalism. Only the outcome of this intellectual discourse could curb support for terrorism causes which might open a new avenue for undermining terrorism recruitment appeal. Definitely testing this statement statistically could be a topic of future behavioral research on terrorism. 
On the workability of such a model, gradualism is preferred over immediacy, the latter will lead to more bloodshed and conflict with political powers whose personal authority might incentivize them into maintaining the institutional status quo. On the other hand, mapping a gradual yet irreversible steps of cooperation will be smoother and ${ }^{\mathrm{i}}$ more sustainable.

\section{References:}

1. Al-Baghdadi, Ahmad Mubarak. "The political thought of Abu AlHassan Al-Mawardi." (1981).

2. An-Na-im, Shari'a and Positive Legislation: Is an Islamic State Possible or Viable, 5 Y.B. Islamic \& Middle E. L. 29, 41 (1998-1999),

3. Daniel J Elazar, Exploring Federalism (2014)

4. Pankhurst, Reza. The Inevitable Caliphate?: A History of the Struggle for Global Islamic Union, 1924 to the Present (p. 191 onward). Oxford University Press.

5. Efraim Benmelech and Esteban F. Klor, "What Explains The Flow Of Foreign Fighters To ISIS?” National Bureau of Economic Research. (2016) SSRN Electronic Journal

6. Esposito, J.L. and Mogahed, D., 2007. Battle for Muslims' Hearts and Minds: The Road Not (yet) Taken. Middle east policy, 14(1),

7. Feldman, N. (2012). The Fall and Rise of the Islamic State. Princeton: Princeton University Press.

8. Felicitas Opwis, "Maslaha In Contemporary Islamic Legal Theory." Islamic Law and Society 12.2 (2005)

9. Gilles Grin, Shaping Europe, the Path to European Integration according to Jean Monnet, Debates and Documents Collection, March 2017

10. Gutmann, Jerg, and Stefan Voigt. "The rule of law and constitutionalism in Muslim countries." Public Choice 162.3-4 (2015): 351-380, p 354

11. Hallaq, W. (2009). Sharīa: theory, practice, transformations. Cambridge University Press, 2009, p 360 For the same conclusion but based on utterly different reasons see Abdullahi A. An-Na-im, Shari'a and Positive Legislation: Is an Islamic State Possible or Viable, 5 Y.B. Islamic \& Middle E. L. 29, 41 (1998-1999)

12. Jackson, Sherman A. "Shari'ah, democracy, and the modern nationstate: some reflections on Islam, popular rule, and pluralism." Fordham Int'l LJ 27 (2003): 105-106.

13. John M. Owen IV, Confronting Political Islam: Six Lessons from the West's Past, (2014). 
14. Jonathon M. Berger and Jonathon Morgan, "The ISIS Twitter Census: Defining and Describing the Population of ISIS Supporters on Twitter." The Brookings Project on US Relations with the Islamic World 3.20 (2015).

15. Khaled Abou El Fadl, Conceptualizing Shari'a in the Modern State. Villanova Law Review, vol. 56, no. 5, (2012).

16. Maeghin Alarid, "Recruitment and Radicalization: The role of Social Media and New Technology." Impunity: Countering illicit power in war and transition: 313-330 (2016). NATO Strategic Communications Centre of Excellence, DAESH Recruitment: How the Group Attracts Supporters, p. 9 available online http://www.stratcomcoe.org/daeshrecruitment-how-group-attracts-supporters- 0.

17. Maurite Berger, Sharia - A Flexible Notion, 35 R \& R 335, 345 (2006)

18. Nader Hashemi, Islam, Secularism, and Liberal Democracy: Toward a Democratic Theory for Muslim Societies,(2009).

19. NATO, 'Daesh Recruitment How The Group Attracts Supporters' (2016) < https://www.stratcomcoe.org/daesh-recruitment-how-groupattracts-supporters-0> See also Daveed Gartenstein-Ross, Nathaniel Barr and Bridget Moreng, “The Islamic State's Global Propaganda Strategy” (2016) Terrorism and Counter-Terrorism Studies, 21; see also Devin R Springer, David N Edger \& James L Regens, Islamic Radicalism and Global Jihad, 11\&146 (2009).

20. Noah Feldman, After Jihad: America and the Struggle for Islamic Democracy, ( 2007)

21. Robert Fatton \& Rouhollah K Ramazani, Religion, State, and Society Jefferson's Wall of Separation in Comparative Perspective, 156-180 (2009).

22. Sunstein, Cass R. Going to extremes, p 108, citing Alan Kruger, What Makes a Terrorist, 89-90; Also see, ignaciosánchez-cuenca, Terrorism and the State, 2014 The Handbook of Rational Choice Social Research, Stanford University Press, at 381,

23. T.R. Gurr, Terrorism in Democracies: Its Social and Political Bases, in Origins of Terrorism ( W. Reich ed. 1998)

24. Tomass, Mark K. "Religious identity, informal institutions, and the nation-states of the near east." Journal of Economic Issues 46.3 (2012): 705-728. Informal institutions and radical ideologies under institutional transformation, Irina Starodubrovskaya, Russian Journal of Economics Volume 1, Issue 2, June 2015, Pages 182-198. On the idea of parallel black market for religion See Also, Zucca, Lorenzo. A secular Europe: Law and religion in the European constitutional landscape. Oxford University Press, 2012, p 120 
25. William E. Scheuerman, "Realists Against the NationState" Transnat'l L. \& Contemp. Probs. 20 (2011) 67.

26. WorldPublicOpinion.org, "Muslim Public Opinion on US Policy, Attacks on Civilians and al-Qaeda" (Maryland: The Center for International and Security Studies at Maryland, 2007), p 15; see also Esposito. and Mogahed, p.28. 